\title{
DENTAL FEAR IN CHILDREN WITH REPEATED TOOTH INJURIES
}

\author{
Dubravka Negovetić Vranić ${ }^{1}$, Nataša Ivančić Jokiće ${ }^{2}$ Danko Bakarčić ${ }^{2}$ Andreja Carek ${ }^{3}$, \\ Željko Rotim ${ }^{4}$ and Željko Verzak ${ }^{1}$
}

${ }^{1}$ Department of Pediatric Dentistry, School of Dental Medicine, University of Zagreb, Zagreb; ${ }^{2}$ Department of Pediatric Dentistry, School of Medicine, University of Rijeka, Rijeka University Hospital Center, Rijeka; ${ }^{3}$ Department of Fixed Prosthodontics, School of Dental Medicine, University of Zagreb, Zagreb; ${ }^{4}$ Private Dental Office, Zagreb, Croatia

\begin{abstract}
SUMMARY - Tooth injuries are serious clinical conditions. Some children experience dental trauma only once, while others are more prone to repeated tooth injuries. Repeated dental trauma occurs in $19.4 \%$ to $30 \%$ of patients. Pain and dental trauma are the most common reasons for fear and anxiety. The main objective of this study was to investigate how dental trauma, as well as repeated dental trauma affects the occurrence and development of dental fear in children. The study was conducted on a random sample of 147 subjects ( 88 boys and 59 girls) aged 5-8 and 9-12 years. Subjects in both age groups were divided into subroups without dental trauma, with one dental trauma and with repeated dental trauma. The validated Children's Fear Survey Schedule - Dental Subscale was used on fear assessment. Results showed that only $12.2 \%$ of children without trauma, $33.3 \%$ with one trauma and $51.7 \%$ with repeated trauma were not afraid of injection. Older children had a significantly lower fear of injections, touch of an unknown person, choking, going to the hospital and people in white uniforms. Dentist was not the cause of fear in $65.5 \%$ of patients with repeated trauma. With each repeated injury of teeth, the degree of their fear of dental treatment was lower.
\end{abstract}

Key words: Tooth injuries; Child; Fear; Dental anxiety

\section{Introduction}

Dental trauma and tooth injury are among the most serious clinical conditions because they pose a psychological, social and therapeutic problem ${ }^{1}$. The prevalence of dental trauma varies between $4.4 \%$ and $66 \%{ }^{2-4}$. Some children experience dental trauma only once, while others are more prone to repeated injuries. Repeated dental trauma occurs in $19.4 \%$ to $30 \%$ of patients ${ }^{5,6}$.

Dental fear is a serious problem that can interfere with treatment plans and implementation of preventive measures ${ }^{7,8}$. In most cases, children visit dentists

Correspondence to: Assist. Prof. Dubravka Negovetić Vranić, DMD, $M S, P h D$, Department of Pediatric Dentistry, School of Dental Medicine, Gundulićeva 5, HR-10000 Zagreb, Croatia

E-mail: dnegovetic@sfzg.hr

Received May 3, 2016, accepted June 14, 2016 for emergency, and the associated pain and trauma are the most common reasons for development of fear and anxiety $^{9,10}$. Pain is personal experience and perception of pain intensity varies depending on a variety of subjective and objective parameters. Children experiencing painful surgery at an early age are at an increased risk of developing dental fear in comparison to those with positive or neutral dental experiences before undergoing their first painful surgery ${ }^{11}$.

Drilling, injections, physical trauma, and dental trauma are a few examples of directly conditioned negative experiences that result in pain. Constitutional and psychosocial factors that contribute to the development of dental fear include fear of medical procedures, fear of 'white coats', age of the child, social conditions, parental and environmental influences, character traits of the child, and the child's existing fears ${ }^{12-14}$. 
The main objective of this study was to investigate how dental trauma affects the occurrence and development of dental fear. Degree of dental fear was determined in children with no experience of dental trauma, in children with single experience of dental trauma, and in children with repeated dental trauma.

\section{Subjects and Methods}

This study was conducted using a convenience sample of 147 subjects ( 88 boys and 59 girls) aged 5-8 and 9-12 years. Of these subjects, 49 had no experience of dental trauma, 69 had experienced dental trauma once, and 29 had repeated dental trauma. All of the patients had permanent maxillary and mandibular incisors, and only patients with dental trauma to these teeth were included in the study. Subjects were patients of the Department of Pediatric Dentistry, School of Medicine, University of Rijeka in Rijeka and Department of Pediatric Dentistry, School of Dental Medicine, University of Zagreb in Zagreb. The study was approved by the Ethics Committee of the School of Medicine, University of Rijeka and procedures were performed according to the Helsinki Declaration from 1975 , as revised in 1983. An informed consent was obtained from the children and their parents. Children filled out the questionnaire in dental clinics after dental examination. Principal investigator assisted the children aged 5-7 years to fill out the questionnaire.

The Children's Fear Survey Schedule - Dental Subscale (CFSS-DS) is the most frequently used psychometric scale for determination of dental fear and was used to assess fear in this study. The CFSS-DS has been validated in a Croatian population ${ }^{15}$. The survey consists of 15 questions (Table 1). The response options for survey items are: 1) not afraid, 2) a little afraid,3) fairly afraid, 4) quite afraid, and 5) very afraid. Total score can range from 15 to 75 points, and the intensity of patient's fear is proportional to the number of points. Patients who have 45 or more points are considered to be highly anxious patients ${ }^{16,17}$.

Data were analyzed used STATISTICA for Windows, Release 5.5 A* and SPSS for Windows, Release $7.5^{* *}$. Total scores were calculated from the questionnaires. Internal consistency was assessed using Cronbach's alpha. Cronbach's alpha was 0.9101 in this study. The $\chi^{2}$-test was used to compare differences in proportions.
Table 1. Children's Fear Survey Schedule - Dental Subscale

\begin{tabular}{|l|l|}
\hline No. & Item \\
\hline 1 & Dentists \\
2 & Doctors \\
3 & Injections \\
4 & Having somebody examine your mouth \\
5 & Having to open your mouth \\
6 & Having a stranger touch you \\
7 & Having somebody look at you \\
8 & The dentist drilling \\
9 & The sight of the dentist drilling \\
10 & The noise of the dentist drilling \\
11 & Having somebody put instruments in your mouth \\
12 & Choking \\
13 & Having to go to the hospital \\
14 & People in white uniform \\
15 & Having the dentist clean your teeth \\
\hline
\end{tabular}

\section{Results}

The distribution of responses to the CFSS-DS items based on age and history of dental trauma and results of the corresponding $\chi^{2}$-test are shown in Tables 2 and 3. Only statistically significant variables are listed. Older children had a significantly lower fear of injections, contact by an unknown person, choking, going to the hospital and people in white uniforms. Other responses to the subscales in the assessment of children's dental fear indicated that younger children were different from older children. Fear somewhat differed according to the history of dental trauma. Dentist was the cause of fear in $55.1 \%$ of children with no history of trauma, $40.6 \%$ of children with one traumatic experience and $34.5 \%$ of children with repeated trauma. Only $12.2 \%$ of children without trauma, $33.3 \%$ with one trauma experience and $51.7 \%$ with repeated trauma were not afraid of injection. Children were less afraid of dental examinations than injections, and in this case, fear differed significantly according to subgroups, i.e. $69.4 \%$ of children without trauma, $88.4 \%$ of children with one trauma, and $89.7 \%$ of children with repeated trauma were not afraid of dental examinations. Having a dental instrument in one's mouth also caused significantly different fears, with $57.1 \%$ of children without trauma, $59.4 \%$ of children 
Table 2. Distribution of responses to dental plan subscale assessment of children's fear according to age (only statistically significant variables are listed)

\begin{tabular}{|c|c|c|c|c|c|c|c|c|}
\hline \multirow{2}{*}{ Child fear of: } & \multirow{2}{*}{$\begin{array}{c}\text { Age } \\
\text { (years) }\end{array}$} & & \multicolumn{5}{|c|}{ Level of fear } & \multirow{2}{*}{$\chi^{2}$-test } \\
\hline & & & Not afraid & A little afraid & Fairly afraid & Quite afraid & Very afraid & \\
\hline \multirow{4}{*}{ Injection } & \multirow{2}{*}{$5-8$} & $\mathrm{n}$ & 7 & 26 & 10 & 4 & 17 & \multirow{4}{*}{$<0.001$} \\
\hline & & $\%$ & $10.9 \%$ & $40.6 \%$ & $15.6 \%$ & $6.3 \%$ & $26.6 \%$ & \\
\hline & \multirow{2}{*}{$9-12$} & $\mathrm{n}$ & 37 & 24 & 17 & 2 & 3 & \\
\hline & & $\%$ & $44.6 \%$ & $28.9 \%$ & $20.5 \%$ & $2.4 \%$ & $3.6 \%$ & \\
\hline \multirow{4}{*}{$\begin{array}{l}\text { Having a } \\
\text { stranger touch } \\
\text { you }\end{array}$} & \multirow{2}{*}{$5-8$} & $\mathrm{n}$ & 25 & 22 & 11 & 3 & 3 & \multirow{4}{*}{0.005} \\
\hline & & $\%$ & $39.1 \%$ & $34.4 \%$ & $17.2 \%$ & $4.7 \%$ & $4.7 \%$ & \\
\hline & \multirow{2}{*}{$9-12$} & $\mathrm{n}$ & 56 & 19 & 3 & 2 & 3 & \\
\hline & & $\%$ & $67.5 \%$ & $22.9 \%$ & $3.6 \%$ & $2.4 \%$ & $3.6 \%$ & \\
\hline \multirow{4}{*}{ Choking } & \multirow{2}{*}{$5-8$} & $\mathrm{n}$ & 7 & 17 & 17 & 2 & 21 & \multirow{4}{*}{0.002} \\
\hline & & $\%$ & $10.9 \%$ & $26.6 \%$ & $26.6 \%$ & $3.1 \%$ & $32.8 \%$ & \\
\hline & \multirow{2}{*}{$9-12$} & $\mathrm{n}$ & 31 & 20 & 18 & 3 & 11 & \\
\hline & & $\%$ & $37.3 \%$ & $24.1 \%$ & $21.7 \%$ & $3.6 \%$ & $13.3 \%$ & \\
\hline \multirow{4}{*}{$\begin{array}{l}\text { Having to go to } \\
\text { the hospital }\end{array}$} & \multirow{2}{*}{$5-8$} & $\mathrm{n}$ & 17 & 20 & 15 & 6 & 6 & \multirow{4}{*}{0.020} \\
\hline & & $\%$ & $26.6 \%$ & $31.3 \%$ & $23.4 \%$ & $9.4 \%$ & $9.4 \%$ & \\
\hline & \multirow{2}{*}{$9-12$} & $\mathrm{n}$ & 43 & 23 & 10 & 4 & 3 & \\
\hline & & $\%$ & $51.8 \%$ & $27.7 \%$ & $12.0 \%$ & $4.8 \%$ & $3.6 \%$ & \\
\hline \multirow{4}{*}{$\begin{array}{l}\text { People in white } \\
\text { uniforms }\end{array}$} & \multirow{2}{*}{$5-8$} & $\mathrm{n}$ & 54 & 4 & 4 & 1 & 1 & \multirow{4}{*}{0.042} \\
\hline & & $\%$ & $84.4 \%$ & $6.3 \%$ & $6.3 \%$ & $1.6 \%$ & $1.6 \%$ & \\
\hline & \multirow{2}{*}{$9-12$} & $\mathrm{n}$ & 81 & 0 & 1 & 1 & 0 & \\
\hline & & $\%$ & $97.6 \%$ & 0 & $1.2 \%$ & $1.2 \%$ & 0 & \\
\hline
\end{tabular}

with one trauma and $62.1 \%$ of children with repeated trauma reporting they were not afraid of instruments inside their mouth. Similarly, 55.1\% of children without trauma, $75.4 \%$ with one trauma and $89.7 \%$ with repeated trauma were not afraid of tooth cleaning at the dentist.

Boys comprised $46.9 \%$ of the subgroup with no history of trauma and $60.9 \%$ of the subgroup with one traumatic experience; there were significantly more boys $(79.3 \%)$ in the subgroup with repeated trauma. Therefore, the risk of re-injury was characteristic of boys (Table 4).

\section{Discussion}

In everyday clinical practice, dentists frequently encounter children showing fear of dental treatment. These children often report a history of negative medical experiences. Often a negative experience is because of dental injury, which has been occurring at an increasing rate in school-age children in particular. Some children experience tooth injury just once, whereas some experience them repeatedly.

Research has shown that tooth injuries have direct negative effects, and are uncomfortable, quite painful and frightening, which can lead to the development of dental anxiety ${ }^{18,19}$. Children with painful dental experiences are more likely to develop a high degree of dental fear and anxiety when they find themselves at the dentist ${ }^{19}$.

However, in the recent literature, data on repeated dental trauma are scarce, with no data on their connection to the development of fear and dental anxiety. According to the results obtained from the CFSS-DS questionnaire, children generally express a moderate degree of fear of dental treatment. Statistically significant differences were found between the two groups of children divided by age and history of dental trauma. Children were shown to be most afraid of injections, dentists, dental examinations, having instruments in their mouth and tooth cleaning ${ }^{20,21}$. In this study, children without trauma expressed the greatest amount of 
Table 3. Distribution of responses to dental plan subscale assessment of children's fear according to dental trauma (only statistically significant variables are listed)

\begin{tabular}{|c|c|c|c|c|c|c|c|c|}
\hline \multirow{2}{*}{ Child fear of: } & \multirow{2}{*}{ Group } & & \multicolumn{5}{|c|}{ Level of fear } & \multirow{2}{*}{$\chi^{2}-$ test } \\
\hline & & & Not afraid & A little afraid & Fairly afraid & Quite afraid & Very afraid & \\
\hline \multirow{6}{*}{ Dentist } & \multirow{2}{*}{ No trauma } & $\mathrm{n}$ & 22 & 10 & 6 & 4 & 7 & \multirow{6}{*}{$<0.001$} \\
\hline & & $\%$ & $44.9 \%$ & $20.4 \%$ & $12.2 \%$ & $8.2 \%$ & $14.3 \%$ & \\
\hline & \multirow{2}{*}{$\begin{array}{l}\text { Single } \\
\text { trauma }\end{array}$} & $\mathrm{n}$ & 41 & 25 & 2 & 0 & 1 & \\
\hline & & $\%$ & $59.4 \%$ & $36.2 \%$ & $2.9 \%$ & 0 & $1.4 \%$ & \\
\hline & \multirow{2}{*}{$\begin{array}{l}\text { Repeated } \\
\text { trauma }\end{array}$} & $\mathrm{n}$ & 19 & 9 & 1 & 0 & 0 & \\
\hline & & $\%$ & $65.5 \%$ & $31.0 \%$ & $3.4 \%$ & 0 & 0 & \\
\hline \multirow{6}{*}{ Injection } & \multirow{2}{*}{ No trauma } & $\mathrm{n}$ & 6 & 23 & 9 & 1 & 10 & \multirow{6}{*}{0.010} \\
\hline & & $\%$ & $12.2 \%$ & $46.9 \%$ & $18.4 \%$ & $2.0 \%$ & $20.4 \%$ & \\
\hline & \multirow{2}{*}{$\begin{array}{l}\text { Single } \\
\text { trauma }\end{array}$} & $\mathrm{n}$ & 23 & 21 & 13 & 5 & 7 & \\
\hline & & $\%$ & $33.3 \%$ & $30.4 \%$ & $18.8 \%$ & $7.2 \%$ & $10.1 \%$ & \\
\hline & \multirow{2}{*}{$\begin{array}{l}\text { Repeated } \\
\text { trauma }\end{array}$} & $\mathrm{n}$ & 15 & 6 & 5 & 0 & 3 & \\
\hline & & $\%$ & $51.7 \%$ & $20.7 \%$ & $17.2 \%$ & 0 & $10.3 \%$ & \\
\hline \multirow{6}{*}{$\begin{array}{l}\text { Dental } \\
\text { examination }\end{array}$} & \multirow{2}{*}{ No trauma } & $\mathrm{n}$ & 34 & 5 & 7 & 3 & 0 & \multirow{6}{*}{0.017} \\
\hline & & $\%$ & $69.4 \%$ & $10.2 \%$ & $14.3 \%$ & $6.1 \%$ & 0 & \\
\hline & \multirow{2}{*}{$\begin{array}{c}\text { Single } \\
\text { trauma }\end{array}$} & $\mathrm{n}$ & 61 & 6 & 1 & 1 & 0 & \\
\hline & & $\%$ & $88.4 \%$ & $8.7 \%$ & $1.4 \%$ & $1.4 \%$ & 0 & \\
\hline & \multirow{2}{*}{$\begin{array}{l}\text { Repeated } \\
\text { trauma }\end{array}$} & $\mathrm{n}$ & 26 & 3 & 0 & 0 & 0 & \\
\hline & & $\%$ & $89.7 \%$ & $10.3 \%$ & 0 & 0 & 0 & \\
\hline \multirow{6}{*}{$\begin{array}{l}\text { Having } \\
\text { somebody put } \\
\text { instruments in } \\
\text { your mouth }\end{array}$} & \multirow{2}{*}{ No trauma } & $\mathrm{n}$ & 28 & 8 & 6 & 3 & 4 & \multirow{6}{*}{0.039} \\
\hline & & $\%$ & $57.1 \%$ & $16.3 \%$ & $12.2 \%$ & $6.1 \%$ & $8.2 \%$ & \\
\hline & \multirow{2}{*}{$\begin{array}{l}\text { Single } \\
\text { trauma }\end{array}$} & $\mathrm{n}$ & 41 & 22 & 5 & 0 & 1 & \\
\hline & & $\%$ & $59.4 \%$ & $31.9 \%$ & $7.2 \%$ & 0 & $1.4 \%$ & \\
\hline & \multirow{2}{*}{$\begin{array}{l}\text { Repeated } \\
\text { trauma }\end{array}$} & $\mathrm{n}$ & 18 & 10 & 1 & 0 & 0 & \\
\hline & & $\%$ & $62.1 \%$ & $34.5 \%$ & $3.4 \%$ & 0 & 0 & \\
\hline \multirow{6}{*}{$\begin{array}{l}\text { Having the } \\
\text { dentist clean } \\
\text { your teeth }\end{array}$} & \multirow{2}{*}{ No trauma } & $\mathrm{n}$ & 27 & 10 & 7 & 4 & 1 & \multirow{6}{*}{0.016} \\
\hline & & $\%$ & $55.1 \%$ & $20.4 \%$ & $14.3 \%$ & $8.2 \%$ & $2.0 \%$ & \\
\hline & Single & $\mathrm{n}$ & 52 & 14 & 2 & 1 & 0 & \\
\hline & trauma & $\%$ & $75.4 \%$ & $20.3 \%$ & $2.9 \%$ & $1.4 \%$ & 0 & \\
\hline & \multirow{2}{*}{$\begin{array}{c}\text { Repeated } \\
\text { trauma }\end{array}$} & $\mathrm{n}$ & 26 & 2 & 1 & 0 & 0 & \\
\hline & & $\%$ & $89.7 \%$ & $6.9 \%$ & $3.4 \%$ & 0 & 0 & \\
\hline
\end{tabular}

fear, while children with one or repeated trauma had significantly less pronounced fear. Older children were significantly less afraid of injections, contact by unknown persons, choking, going to the hospital and people in white uniforms. Younger children, regardless of their history of tooth injuries, reacted at the level of their psychological development and expressed increased fear in given situations. The results showed that fear decreased with the number of experienced traumas, suggesting that a child with a history of dental trauma may have more experience with dentists and dental treatment, therefore potentially perceiving less pain. Accordingly, dental trauma as a previous negative experience does not necessarily have negative implications.

A child suffering a dental injury has to contact the dentist out of necessity and therefore must accept dental treatment. However, if children can see that visiting the dentist is not always so painful and uncomfortable, they may understand how to address their dental fears. The way in which children are taught to adapt to stressful situations depends on the mental characteris- 
Table 4. Dental trauma experience according to gender

\begin{tabular}{|l|l|c|c|c|}
\hline \multirow{2}{*}{ Group } & \multirow{2}{*}{ No trauma } & \multicolumn{2}{|c|}{ Gender } & \multirow{2}{*}{ Total } \\
\cline { 3 - 4 } & $\mathrm{n}$ & Male & Female & \\
\hline & $\mathrm{hp}$ & $46.9 \%$ & $53.1 \%$ & $100.0 \%$ \\
& $\mathrm{vp}$ & $26.1 \%$ & $44.1 \%$ & $33.3 \%$ \\
\hline \multirow{2}{*}{ Single } & $\mathrm{n}$ & 42 & 27 & 69 \\
trauma & $\mathrm{hp}$ & $60.9 \%$ & $39.1 \%$ & $100.0 \%$ \\
& $\mathrm{vp}$ & $47.7 \%$ & $45.8 \%$ & $46.9 \%$ \\
\hline \multirow{2}{*}{ Repeated } & $\mathrm{n}$ & 23 & 6 & 29 \\
trauma & $\mathrm{hp}$ & $79.3 \%$ & $20.7 \%$ & $100.0 \%$ \\
& $\mathrm{vp}$ & $26.1 \%$ & $10.2 \%$ & $19.7 \%$ \\
\hline \multirow{2}{*}{ Total } & $\mathrm{n}$ & 88 & 59 & 147 \\
& $\mathrm{hp}$ & $59.9 \%$ & $40.1 \%$ & $100.0 \%$ \\
\hline$\chi^{2}$-test & & $\chi^{2}=8.000$ & $\mathrm{df}=2$ & $\mathrm{p}=0.018$ \\
\hline
\end{tabular}

$\mathrm{hp}=$ horizontal group percentage; $\mathrm{vp}=$ vertical group percentage

tics of the individual, the level of their intellectual development, and the impact of the environment and other persons. This confirms the hypothesis on the impact of cognitive processes and time factors in the perception of fear.

In this study, we found no statistically significant differences in the degree of dental fear between boys and girls, regardless of their history of dental trauma. However, many authors have reported a significant difference in the level of dental anxiety and fear of dental treatment between boys and girls, stating that dental fear is more pronounced in girls. This could explain the vulnerability of girls and their reaction to the painful and unpleasant procedures that occur during dental operations ${ }^{7,22,23}$. Some authors have referred to a higher level of dental fear in boys ${ }^{24}$, while other studies have shown the same level of fear in both sexes s $^{17,25,26}$.

Regarding the relationship between age and dental fear, this study showed that children in older age groups were less afraid than younger children. This can be explained by changes due to the growth and development of enhanced self-control and the use of a rational approach in stressful situations, such as dental procedures. Some studies have confirmed that fear of dental treatment decreases with increasing age because children have control over the way they express fear ${ }^{15,27,28}$.

This supports the idea that if children can gain experience or become familiar or accustomed with an upcoming dental procedure, then this could reduce the level of their fear and dental anxiety related to the situation. These results indicate that dental fear is lessened if the child has experienced dental trauma. This suggests that children who have one or more traumatic dental experiences are likely to have less fear of upcoming dental surgeries because of their prior experiences at the dentist. This confirms the idea that the development of dental fear can be mitigated if children are trained and aware of upcoming dental procedures, as occurred naturally in children with previous dental experience. In conclusion, after experiencing dental injuries, children are forced to seek and accept dental help and treatment. Upon being treated, they are able to face their fear of dental treatment, and with each repeated tooth injury, the degree of their fear of dental treatment decreases.

\section{References}

1. Ivancic Jokic N, Bakarcic D, Fugosic V, Majstorovic M, Skrinjaric I. Dental trauma in children and young adults visiting a university dental clinic. Dent Traumatol. 2009;25:84-7.

2. Zengin AZ, Celenk P, Sumer AP, Cankaya S. Evaluation of traumatic dental injuries in a group of Turkish population. Niger J Clin Pract. 2015;18:86-9. doi: 10.4103/1119-3077.146985

3. Bilder L, Margvelashvili V, Sgan-Cohen H, Kalandadze M, Levin L, Ivanishvili R, et al. Traumatic dental injuries among 12- and 15-year-old adolescents in Georgia: results of the pathfinder study. Dent Traumatol. 2015;20. doi: 10.1111/ edt.12236.

4. Zaleckiene V, Peciuliene V, Brukiene V, Drukteinis S. Traumatic dental injuries: etiology, prevalence and possible outcomes.Stomatologija. 2014;16:7-14.

5. Al-Jundi SH. Type of treatment, prognosis, and estimation of time spent to manage dental trauma in late presentation cases at a dental teaching hospital: a longitudinal and retrospective study. Dent Traumatol. 2004;20:1-5.

6. de Carvalho Rocha MJ, Cardoso M. Traumatized permanent teeth in Brazilian children assisted at the Federal University of Santa Catarina, Brazil. Dent Traumatol. 2001;17:245-9.

7. Faye M, Yama A, Gueye-Diagne MC, Ba I. Study of fear of dental treatments in pediatrics in Senegal. Dakar Med. 2004; 49:91-5.

8. Fayle SA, Tahmassebi JF. Paediatric dentistry in the new millennium: 2. Behaviour managment-helping children to accept dentistry. Dent Update. 2003;30:294-8.

9. Do C. Applying the social learning theory to children with dental anxiety. J Contemp Dent Pract. 2004;1:126-35. 
10. Taani DQ. Dental attendance and anxiety among public and private school children in Jordan. Int Dent J. 2002;52:25-9.

11. Versloot J, Veerkamp JSJ, Hoogstraten J. Dental Discomfort Questionnaire: assessment of dental discomfort and/or pain in very young children. Comm Dent Oral Epidemiol. 2006;34: 47-52.

12. De Jongh A, van der Burg J, van Overmeir M, Aartman I, van Zuuren FJ. Trauma-related sequelae in individuals with a high level of dental anxiety. Does this interfere with treatment outcome? Behav Res Ther. 2002;40:1017-29.

13. Majstorovic M, Veerkamp JSJ. Needle phobia, its role in the development of dental anxiety. J Dent Child. 2004;3:202-5.

14. ten Berge M, Veerkamp JSJ, Hoogstraten J, Prins PJM. On the structure of childhood dental fear, using the dental subscale of the Children's Fear Survey Schedule. Eur J Paed Dent. 2002; 3:73-8.

15. Majstorovic M, Veerkamp JS, Skrinjaric I. Reliability and validity of measures used in assessing dental anxiety in 5- to 15-year-old Croatian children. Eur J Paediatr Dent. 2003;4: 197-202.

16. Folayan MO, Idehen EE, Ufomata D. The efect of sociodemographic factors on dental anxiety in children seen in a suburban Nigerian hospital. Int J Paediatr Dent. 2003;13:20-6.

17. Wogelius P, Poulsen S, Toft Sørensen H. Prevalence of dental anxiety and behavior management problems among six to eight year old Danish children. Acta Odontol Scand. 2003;61: 178-83.

18. Townend E, Dimigen G, Fung D. A clinical study of child dental anxiety. Behav Res Ther. 2000;38:31-46.

19. Wogelius P, Poulsen S. Associations between dental anxiety, dental treatment due to toothache, and missed dental appoint- ments among six- to eight-year-old Danish children: a crosssectional study. Acta Odontol Scand. 2005;63:179-82.

20. Beena J. Dental subscale of Children's Fear Survey Schedule and dental caries prevalence. Eur J Dent. 2013;7:181-5.

21. Raj S, Agarwal M, Aradhya K, Konde S, Nagakishore V. Evaluation of dental fear in children during dental visit using Children's Fear Survey Schedule - Dental Subscale. Int J Clin Pediatr Dent. 2013;6:12-5.

22. Klages U, Ulusoy O, Kianifard S, Wehrbein H. Dental trait anxiety and pain sensitivity as predictors of expected and experienced pain in stressful dental procedures. Eur J Oral Sci. 2004;112:477-83.

23. Ilieva E, Veleganova V, Petrova S, Belcheva A. A study on fear provoking factors in students from the town of Plovdiv. Folia Med (Plovdiv). 2001;43:16-9.

24. Klinberg G, Berggren U, Noren JG. Dental fear in an urban Swedish child population: prevalence and concomitant factors. Comm Dent Health. 1994;11:208-14.

25. Thomson WM, Locker D, Poulton R. Incidence of dental anxiety in young adults in relation to dental treatment experience. Comm Dent Oral Epidemiol. 2000;28:289-94.

26. Coric A, Banozic A, Klaric M, Vukojevic K, Puljak L. Dental fear and anxiety in older children: an association with parental dental anxiety and effective pain coping strategies. J Pain Res. 2014;7:515-21.

27. Rantavuori K, Lahti S, Hausen H, Seppä L, Kärkkäinen S. Dental fear and oral health and family characteristics of Finnish children. Acta Odontol Scand. 2004;62:207-13.

28. Peretz B, Nazarian Y, Bimstein E. Dental anxiety in a students' paediatric dental clinic: children, parents and students. Int J Paediatr Dent. 2004;14:192-8.

Sažetak

\section{DENTALNI STRAH U DJECE S PONOVLJENOM TRAUMOM ZUBA}

\section{Negovetić Vranić, N. Ivančić Jokić, D. Bakarčić, A. Carek, Ž. Rotim i Ž. Verzak}

Ozljede zubi su ozbiljno kliničko stanje. Neka djeca doživljavaju dentalne traume samo jednom, dok su druga sklonija ozljedama i ponavljanju trauma zubi. Ponovljene traume zuba javljaju se u 19,4\% do 30\% bolesnika. Bol i trauma zuba su najčešći razlozi straha i tjeskobe. Glavni cilj ovoga istraživanja bio je ispitati kako zubna trauma utječe na pojavu i razvoj dentalnog straha. Istraživanje je provedeno na slučajnom uzorku od 147 ispitanika (88 djevojčica i 59 dječaka) u dobi od 5-8 i 9-12 godina. Ispitanici u obje dobne skupine podijeljeni su u tri poskupine: bez dentalne traume, $\mathrm{s}$ jednom dentalnom traumom is ponovljenom dentalnom traumom. U procjeni straha korišten je validirani test Children's Fear Survey Schedule - Dental Subscale test. Starija djeca su imala značajno niži stupanj straha od injekcija, dodira nepoznate osobe, gušenja, odlaska u bolnicu i ljudi u bijelim uniformama. Strah od stomatologa nije imalo 65,5\% djece s ponovljenom traumom. Samo $12,2 \%$ djece bez trauma, $33,3 \%$ s jednom i $51,7 \%$ s ponovljenom traumom se ne boje injekcije. Sa svakom ponovljenom ozljedom zuba stupanj njihovog straha od stomatološkog liječenja je manji.

Ključne riječi: Zub, ozljede; Dijete; Strah; Zubi, anksioznost 